\title{
Een andere kijk
}

\section{FRANS HOOGEVEEN}

\author{
hoofdredacteur
}

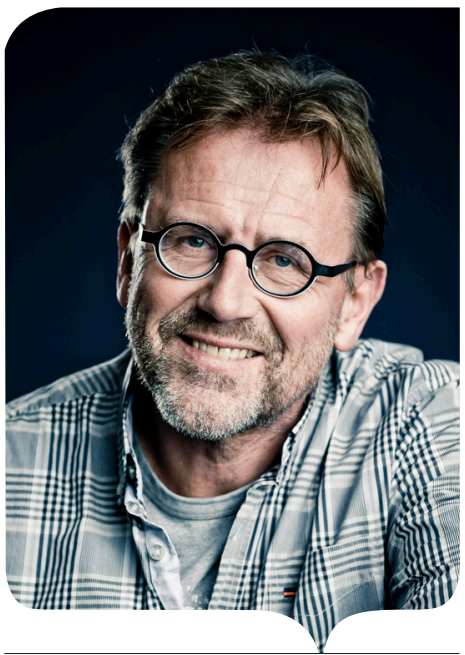

n dit nummer van Denkbeeld breekt Han Diesfeldt een lans voor activiteitenbegeleiding als vak apart. In zijn bespreking van wetenschappelijk onderzoek laat hij zien dat noch gevorderde dementie, noch moeilijk hanteer gedrag een individueel activiteitenplan in de weg hoeft te staan. Dat is een heel andere kijk dan de pessimistische zienswijze dat er bij gevorderde dementie zo weinig mogelijkheden overblijven.

Dergelijk pessimisme vormde ook de aanleiding voor een aanvaring die ik onlangs in het verpleeghuis had met een fysiotherapeut. Voor een cliënt met gevorderde dementie had ik een bewegingsprogramma voorgesteld dat een aantal te trainen onderdelen bevatte. De fysiotherapeut had echter erg weinig vertrouwen in de kans op succes. Op mijn vraag waarom antwoordde hij dat de betreffende cliënt naar zijn inschatting 'niet meer leerbaar' was. Mijn reactie was eruit voordat ik er erg in had: 'Weet je wie er niet meer leerbaar is? Jij! Erg pinnig dat geef ik toe, maar misschien niet geheel onterecht. Dementie is een proces en aan het begin daarvan heeft iemand nog relatief veel mogelijkheden en weinig beperkingen; tegen het einde ervan geldt het omgekeerde, dat is waar. Maar totdat iemand overlijdt blijven er mogelijkheden bestaan, hoe gering ook. En het is aan ons, professionals, om de cliënt te helpen 'eruit te halen wat erin zit', in elke fase van het dementieproces.

Een sprekend voorbeeld van wat mensen met dementie nog allemaal kunnen, lezen we in het interview dat
えFrans Hoogeveen is hoofdredacteur van Denkbeeld, gz-psycholoog bij Florence en zelfstandig gevestigd specialist dementiezorg.

Hugo van Waarde had met Ans Rutges en haar dochter Manon. Ans heeft Alzheimer en woont in een beschermde omgeving, maar is bijzonder actief. Zo werkt ze mee aan allerlei publicitaire activiteiten rond dementie. Om haar in toenemende mate falende geheugen te compenseren maakt ze elke dag met de iPad foto's van dingen die ze meemaakt. En wat blijkt? Als ze 's avonds met haar dochter die foto's bekijkt, weet ze allerlei herinneringen rond die gebeurtenissen op te roepen die anders ontoegankelijk zouden blijven. Ze gebruikt de iPad als haar harde schijf, een geheugenprothese eigenlijk zoals die waar psycholoog Han Stakenburg in het eerste nummer van deze jaargang over schreef. En dat terwijl Ans voor haar dementie nooit een tablet in handen heeft gehad. Zorgboerin Corrie heeft haar op de dagbesteding geleerd met de iPad om te gaan. Dus hoezo: mensen met dementie kunnen niet meer leren? Op de website www.opnieuwgeleerdoudgedaan. $n l$ vindt $\mathrm{u}$ vele clips van mensen met dementie die op verrassende wijze nieuwe dingen leren of oude vaardigheden herontdekken. Verplichte kost voor pessimisten! In de rubriek De Stelling pleit onze redacteur Patrick Verhaest eveneens voor een andere blik op dementiezorg. In die zorg lijkt 'minder problemen' veruit de belangrijkste maatstaf te zijn voor goed werk, zo stelt hij: minder agitatie, minder apathie, minder depressie, minder desoriëntatie. In het zoeken naar een zo goed mogelijke begeleiding van mensen met dementie bewandelen we met dat doel voor ogen vooral het pad van de interventie. En daar plaatst hij vraagtekens bij. Niet de vraag: 'Hoe moet ik het doen?' is zijn inziens het beginpunt van goede zorg, maar: 'Wat telt voor deze persoon op dit moment?' Daarbij is 'aandachtig contact maken (...) wellicht de belangrijkste interventie'.

Kortom, zet uw leerbril op, lees dit nummer van Denkbeeld en toets uw kijk op dementie! 